\title{
ANALISIS PENGARUH BETA SAHAM, DEBT TO EQUITY RASIO (DER) TERHADAP RETURN ON ASSET (ROA) PERUSAHAANDIBURSA EFEK INDONESIA
}

\author{
Muhammad Ikhsan ${ }^{1}$, Eko Budi Santoso ${ }^{2}$ \\ Sekolah Tinggi Ilmu Ekonomi Indonesia \\ Jl. Kayu Jati Raya No. 11A, Rawamangun - Jakarta 13220, Indonesia \\ ikhsanbni84@gmail.com
}

\begin{abstract}
Abstrak Perhitungan rasio keuangan penting bagi perusahaan.. Investor dapat melihat kinerja perusahaan apakah perusahaan berkinerja baik dibandingkan dari rata-rata industri. Rasio adalah ukuran perbandingan antara pos dalam laporan keuangan dengan pos lainnya. Misalnya rasio profitabilitas yaitu Return on Asset makin tinggi ROA makin baik karena Net income makin tinngi. Demikian juga Debt to Equity ratio yaitu berapa batasan berhutang yang ideal yaitu financial leverage berapa ukuran maksimal sehingga net income maksimal.Resiko sistematis atau Beta saham didapat dari slope hasil regresi antara ekses return saham dengan ekses pasar adalah ukuran resiko juga dalam berinvestasi saham . Resiko adalah hal yang menyimpang dari target yang kita inginkan atau sesuatu pencapaian yangberbeda dari hal atau sesuatu yang kita inginkan atau harapkan. Contoh Resiko berinvestasi adalah jika kita menderita kerugian atau kehilangan pokok yang kita tanankan. Resiko yang mempengaruhi saham di bursa yaitu bisa resikosistematik atau bisa juga resiko unsistematis atau resiko di dalam perusahaan misalnya manajemennya. Resiko sistematisjuga disebut resiko pasar yang menimpa semua saham seperti pengaruh dari luar yaitu inflasi, kurs mata uang atau kebijakan pemerintah.Penelitian ini akan membahas apakah ada pengaruh Debt to equity ratio dan beta saham/ resiko sistematis terhadap nilai ROA karena bagi perusahaan net income adalah penting juga bagi investor untuk membeli saham.Sampel datayang diambil penulis sebanyak 35 macam saham dengan cara mengambil secara acak saham-saham yang ada di Bursa efek Indonesia. Data sampel akan diolah dengan statistik menjadi informasi dalam menjawab permasalahan dengan Aplikasi SPSS edisi 19. Hasil penelitian ini yaitu secara bersama-sama variabel Debt to Equity ratio dengan Beta saham mempunyai pengaruh yang signifikan terhadap Return on Equity (ROA) perusahaan di Bursa Efek Indonesia
\end{abstract}


Kata kunci beta saham, systematik Risk, Return on asset (ROA), Rasio, investasi saham

\begin{abstract}
Calculation of finance ratios is important for the company. Investors can view the performance of the company if the company performs well compared to the average industry. The ratio is a measure of the ratio between account in the financial statements with another accounts. For example profitability ratios Return on Assets( ROA) higher is better because Net income increasing. Likewise with Debt to Equity ratio, is how much restriction ideal loanlikethe ideal size of financial leverage to maximum net income. Beta is a systematic risk obtained from the slope of the regression results between excess stock returns with excess return of the capital market index. This is a measure of risk in stock investing. Risk is something that deviates from the target that we want or something less achievement from thing or something we want or expect. Examples of investment risk is if we suffer any loss of money that we invest. Risks of invest stocks is a systematic risk or a unsystematis risk for examplelike a management in the company. Systematic risk is also called market risk hapend to all shares like outside influence,for example inflation, foreign exchange rates or government policy. This research will address the influence Debt to equity ratio and beta stocks / systematic risk to the value of Return of Asset (ROA) because for the company's net income is important for investors to decide buy shares. Sample data is retrieved author as many as 35 kinds of stocks by taking random stocks that exist in the Indonesian Stock Exchange. The sample data will be processed with statistical information in the answer problems with SPSS applications editions 19. Results of this research is jointly variable Debt to Equity ratio with Beta stocks have a significant influence on Return on Equity (ROA) companies in Indonesia Stock Exchange
\end{abstract}

Keywords: beta stocks, systematik Risk, Return on Asset (ROA), ratio, stock investmen 


\section{PENDAHULUAN}

Pasar modal adalah gambaran institusi yang di dalamnya memiliki organisasi yang besar. Di dalam pasar modal ada organisasi yang mengawasi jalannya pasar modal dan ada organisasi yang menjalankan pasar modal. Bursa efek Indonesia adalah organisasi yang menjalankan pasar modal di Indonesia. Pasar modal adalah tempat berkumpulnya orang yang akan mencari modal dan orang yang menyediakan modal sehingga dalam pasar modal ada orang yang akan membeli efek dan ada orang yang akan menjual efek. Banyak orang yang tertarik menulis mengenai pasar modal. Penulis juga tertarik ingin menulis mengenai pasar modal yang didalamnya terdapat produk yang akan diperjual belikan seperti saham, obligasi, option, reksadana dan lain-lain.

Dalam penelitian ini penulis akan mengambil masalah apakah resiko sistematis (beta saham) dipengaruhi oleh debt to equity ratio (DER) dan Return on Asset (ROA), apakah ROA juga dipengaruhi beta saham dan debt to equity ratio. Masalah beta saham / resiko sistematis sangat berpengaruh dalam harga saham sehingga Investor memerlukan banyak informasi untuk memutuskan dalam membeli saham sehingga dikemudian hari hasilnya akan menguntungkan investor.

Saham adalah anggapan nyata dari suatu perusahaan, jika saham perusahaan itu naik maka dianggap perusahaan sedang berkembang dan diharapkan dikemudian hari perusahaan itu akan menghasilkan laba yang tinggi. Investor menganggap bahwa saham adalah gambaran perusahaan maka jika harga saham naik dianggap perusahaan itu baik. Membeli suatu saham juga harus memperhatikan resiko saham tersebut yaitu resiko bawaan maupun resiko sistematisnya maka dianggap saham tersebut mempunyai resiko yang besar karena resiko sistematis maupun resiko bawaannya adalah besar.

Sebagai pembatasan masalah penulis hanya mengambil sampel-sampel dari perusahaan yang telah listing di bursa efek Indonesia dan diambil secara acak sebanyak 35 perusahaan yang dianggap mewakili perusahaan di Bursa Efek Indonesia.

Sistematika penulisan jurnal ini adalah :

a. Pendahuluan yang berisi mengenai mengapa penulis mengambil tema saham\

b. Landasan teori adalah mengenai teori mengenai rasio- rasio perusahan yaitu ROA, sistematis risk atau beta saham serta teori berinvestasi di pasar modal

c. Hasil dan pembahasan berisi mengenai hasil penemuan dan analisis hasil regresi berganda dihubungkan dengan teori 
d. Kesimpulan dan saran berisi kesimpulan dan saran dari penulis

e. Daftar Pustaka adalah buku, jurnal atau tulisan ilmiah dalam media sosial yang menjadi referensi dalam tulisan ini.

\section{LANDASAN TEORI}

\subsection{Rasio Laporan Keuangan perusahaan}

Perusahaan dikatakan berkinerja baik jika laba perusahaan terus meningkat . Dengan meningkatnya laba perusahaan maka dikatakan manajemen perusahaan telah membuat kekayaan pemilik perusahaan bertambah. Akibatnya harga saham perusahaan akan meningkat karena ada tambahan net income perusahaan sehingga total modal akan semakin besar.

Rasio-rasio dari laporan keuangan perusahaan adalah ukuran-ukuran dari berbagai kinerja perusahaan baik mengukur berapa net income yang perusahaan dapatkan, peningkatan penjualan, peningkatan jumlah hutang, peningkatan uang kas yang semuanya akan diukur. Apakah perusahaan berkinerja baik atau perusahaan berkinerja kurang baik dilihat dari rasio-rasio keuangan tersebut apakah angka rasio itu baik. Dapat juga rasio keuangan perusahaan akan dibanding dengan rasio dari rata-rata industrinya.

Ada beberapa jenis rasio untuk mengukur kinerja perusahaan yaitu :
a. Rasio likuiditas
b. Rasio solvabilitas
c. Rasio profitabilitas
d. Rasio aktivitas

Return on asset (ROA) rasio adalah rasio return pada asset dengan rumus sebagai berikut :

$$
\text { ROA }=\frac{\text { Net Income }}{\text { Total asset }}
$$

Dari rumus tersebut dapat dilihat bahwa semakin tinggi net income yang dihasilkan suatu perusahaan maka akan semakin besar ROA yang akan didapatkan.

Untuk Debt to Equity rasio (DER) adalah rasio solvabilitas perusahaan yaitu seberapa besar perbandingan yang efisien antara utang perusahaan dibandingkan dengan equity perusahaan sehingga rumus untuk DER adalah : 


$$
\text { DER }=\frac{\text { Debt }}{\text { Equity }}
$$

Dari rumus tersebut dapat dilihat bahwa rasio DER yang tinggi akan dihasilkan jika Debtnya semakin tinggi yang berakibat nilai DER akan semakin tinggi.

\subsection{Resiko Perusahaan}

Resiko sangat penting bagi investor dalam menentukan untuk membeli saham atau tidak. Dengan mengetahui resiko dari suatu investasi yang akan dia tanamkan maka dia akan mengetahui juga berapa return yang akan dia harapkan. Di dunia investasi dikenal istilah high risk high return yaitu semakin besar resiko yang dia terima maka semakin besar pula return yang akan dia terima. Resiko di dalam membeli saham ada yang dikenal dengan resiko bawaan dari perusahaan dan ada juga resiko sistematis yang menimpa semua saham yaitu resiko yang menimpa semua saham di pasar modal atau juga dikenal dengan resiko pasar. Cara menghitung resiko sistematis saham di pasar modal adalah sama dengan slope dari regresi yang didapatkan antara ekses return dari saham dengan ekses return dari indek harga saham gabungan (IHSG). Dengan demikian resiko sistematis akan berhubungan dengan return suatu saham sedangkan return saham juga berhubungan dengan harga saham sehingga diharapkan dari membaca tulisan ini kita dapat menentukan berapa harga saham dan berminat membeli saham. Dalam manajemen keuangan juga dikenal ada rumus untuk hubungan antara resiko dengan return yang kita harapkan yaitu Capital Asset Pricing model (CAPM) menentukan model harga capital asset sebagai berikut :

$E(R)=R f+\beta(R m-R f)$

Penjelasan :

$\mathrm{E}(\mathrm{R})$ : Expected return saham

Rf : Risk free

$\beta \quad$ : beta (resiko sistematis)

$\mathrm{Rm}$ : Return market di pasar modal

Dilihat dari rumus diatas maka seorang investor yang akan berinvestasi dengan membeli saham juga harus mempehatikan resiko saham tersebut, makin tinggi resiko yang dia terima makin tinggi return yang dia inginkan. Rumus dari return adalah sebagai berikut : 


\section{Return $=\underline{\text { Harga jual }- \text { harga beli }} \times 100 \%$ \\ Harga beli}

sehingga jika investor ingin mendapatkan return yang tinggi dia harus dapat menjual sahamnya diatas jauh dari harga belinya.

\subsection{Investasi}

Investasi adalah suatukegiatan untuk mendapatkan nilai lebih dari apa yang telah ditanamkan oleh investor baik berupa membuat perusahaan, membeli tanah, membeli emas atau juga membeli efek di Bursa Efek Indonesia. Kegiatan ini dilakukan oleh investor dengan harapan memperoleh keuntungan lebih dari apa yang telah dia beli sehingga investor mendapatkan uang masuk yang lebih banyak dari uang yang telah dia keluarkan.

Berbagai macam seseorang melakukan investasiseperti melakukan pembelian saham atau obligasi di pasar modal atau melakukan pembelian barang-barang secara fisik yang akan dijual di masa datang dengan harapan adanya selisih harga atau juga mendirikan perusahan bertujuan untuk meningkatkan kesejahteraan hidupnya.

Barang yang dibeli oleh investor tersebut bisa berwujud tanah, rumah, perusahaan, perhiasan bahkan juga bisa berupa kendaraan dengan maksud jika dijual di kemudian hari akan mendapatkan selisih lebih uang dari harga belinya.

Proses pembelian barang yang diharapkan akan menghasilkan keuntungan bagi yang berinvestasi harus dengan perhitungan yang matang karena diharapkan investasi tersebut akan meningkat harga jualnya. Contoh Jika kita membeli emas 1 gram Rp. 500.000 diharapkan tahun berikutnya menjadi Rp. 600.000,-. Jika kita membeli tanah 1meter persegi Rp. 1.000.000,- diharapkan tahun berikutnya menjadi Rp. 2.000.000,-Begitulah seorang investor berfikirnya dengan mengharapkan keuntungan menjadi berlipat ganda pada tahun berikutnya. Demikian juga jika kita membeli perusahaan diharapkan perusahaan itu akan berkembang dengan laba yang semakin besar.

Cara berinvestasi di Pasar modal dengan membeli berbagai macam saham diharapkan harga jual saham dikemudian hari akan meningkat berkali-kali lipat. Dengan membeli saham kita mengharapkan perusahaan yang sahamnya kita beli akan semakin maju dan berkembang yang akan berakibat kepada harga sahamnya yang akan semakin meningkat ditahun-tahun mendatang.Contohnya jika kita membeli seharga Rp. 1.000 per lembar saham maka diharapkan pada tahun depan akan menjadi Rp. 1.500,-. 
Investasi lain kita yaitu dengan membuat suatu perusahaan dan kita menjalankan perusahaan tersebut sehingga berkembang dengan penjualan lebih banyak yang pada akhirnya akan menghasilkan laba perusahaan yang berlipat ganda sehingga total ekuitas perusahaan akan bertambah yang notabene akan menambah kekayaan pemegang saham perusahaan.

Kita membeli saham jika saham itu yakin di kemudian hari akan meningkat harga jualnya. Bagaimana harga jual akan naik jika saham tersebut tidak berpotensi untuk naik. Banyak teknik analisis untuk melihat potensi kenaikan harga saham misalnya dengan fundamental analisis yaitu melihat kinerja keuangan perusahaan dengan melihat rasio-rasio keuangan perusahaan apakah rasio baik atau masih kurang baik. Teknik lain yaitu dengan teknical analysis yaitu dengan memprediksi perkembangan harga saham ke depannya yaitu memprediksi harga saham apakah trend harga saham itu akan naik atau akan turun.

\section{HASIL PENELITIAN DANPEMBAHASAN}

\subsection{Objek Penelitian}

Adalah data-data dari Rasio profitabilitas pada perusahaan yang listing di bursa saham berupa data ROA, rasio solvabilitas yaitu Debt to Equity Ratio (DER) serta beta dari masing-masing saham. Dalam melakukan penelitian ini penulis akan mengambil sampel return on asset (ROA) dan Debt to Equity Ratio (DER) serta sistematik risk/beta saham $(\beta)$.

Data ROA adalah data rata-rata ROA selama 5 tahun terakhir dari perusahaan sedangkan Debt To Equity Ratio (DER) adalah data terakhir dari laporan keuangan perusahaan yang penulis ambil di bulan Maret 2016 demikian juga data beta saham. Saham yang akan menjadi sampel dalam penelitian ini adalah 35 saham yang terdaftar di Bursa Efek Indonesia yang diambil secara acak oleh penulis.

\subsection{Metode Penelitian}

Untuk dapat memperoleh suatu data dan informasi yang diperlukan dalam penelitian maka dapat digunakan metode sebagai berikut :

1. Metode Observasi dengan mengadakan suatu pengamatan secara langsung dilapangan terhadap suatu kegiatan sehingga dia ikut terlibat pada objek yang akan diteliti. 
2. Metode Interview dengan mengadakan wawancara dengan pelaku kegiatan seperti pemilik perusahaan atau para ahli yang di bidangnya.

3. Metode Dokumentasi dengan mengadakan penelitian terhadap laporan keuangan perusahaan, kegiatan operasional perusahaan, struktur organisasi, manajemen atau data olahan lainnya yang dipublikasikan di media sosial seperti internet atau surat kabar

\subsection{Jenis data}

- Data Kualitatif yaitu data yang merupakan kumpulan dari data yang bukan angka tetapi berupa tulisan huruf, pengamatan atau ucapan dari para pakar di bidangnya.

- Data Kuantitatif yaitu data yang merupakan kumpulan dari data angka-angka seperti data ukuran atau rasio seperti data ROA, DER serta beta saham.

\subsection{Sumber Data}

- Data Primer adalah data yang didapat atau dikumpulkan selama melakukan penelitian dengan cara didapat langsung dari responden atau ahlinya dengan melakukan wawancara, melakukan pengisian kuesioner atau observasi langsung

- Data Sekunder adalah data yang diperoleh dari pihak lain atau pihak ketiga yang melakukan publikasi data seperti berita, jurnal dan buku literatur,observasi kepustakaan atau data olahan lainnya dari perusahaan yang dipublikasikan seperti laporan keuangan, rasio keuangan dan beta saham

\subsection{Variabel Penelitian}

Ada 2 (dua) macam variabel penelitian yaitu variabel bebas (X) dan variabel tergantung $(\mathrm{Y})$.

1) Variabel Bebas $(X)$

Variabel X adalah variabel bebas yaitu variabel yang berdiri sendiri dan diharapkan akan mempengaruhi variabel dependent atau variabel tergantung. Variabel bebas dalam penelitian ini adalah Beta saham dan Debt to equity Ratio.

- Beta saham/ $\beta$ (X1)

adalah slope dari hasil regresi antara ekses return dari saham dengan ekses return dari indeks harga saham gabungan (IHSG). Beta saham dalam penelitian ini didapat dari hasil olahan publikasi perusahaan yang sudah listing di Bursa Efek Indonesia 
- Debt to Equity Ratio / DER (X2)

adalah rasio solvabilitas yang didapat dari total hutang dibagi dengan total equity. DER dalam penelitian ini didapat dari hasil olahan perusahaan yang sudah listing di Bursa Efek Indonesia.

2) Variabel Tergantung $(Y)$

Variabel Y merupakan variabel tergantung yang dipengaruhi oleh variabel bebas baik dalam bentuk hubungan atau pengaruhnya. Variabel tergantung adalah ROA dari saham yang sudah listing di bursa efek Indonesia yaitu rata-rata ROA selama 5 tahun terakhir.

\subsection{Hasil Uji statistik}

Hasil dari proses uji statistik terhadap data ROA, DER dan beta saham yang berasal dari olahan laporan keuangan perusahaan yang terdaftar di Bursa efek Indonesia dan diambil secara acak sampel sebanyak 35 perusahaan didapat hasil sebagai berikut :

Hasil dari Pengujian data dengan menggunakan aplikasi SPSS,

Uji asumsi Klasik :

\section{Uji Multikolinieritas}

Uji ini bertujuan untuk menguji apakah antar variabel independent mempunyai hubungan langsung (berkolerasi) sempurna. Jika ya maka kedua variabel independent tidak bisa digunakan secara bersama-sama sebagai variabel independent. Jika bebas dari masalah multikolinieritas, maka kedua variabel independent tersebut layak untuk digunakan secara bersama-sama dalam pengujian regresi berganda.

Dari hasil uji multikolinearitas dikatakan bebas dari masalah multikolineritas

Coefficients $^{\mathrm{a}}$

\begin{tabular}{|c|c|c|c|c|c|c|c|}
\hline \multirow[b]{2}{*}{ Model } & \multicolumn{2}{|c|}{$\begin{array}{l}\text { Unstandardized } \\
\text { Coefficients }\end{array}$} & \multirow{2}{*}{$\begin{array}{c}\begin{array}{c}\text { Standardize } \\
\mathrm{d} \\
\text { Coefficients }\end{array} \\
\text { Beta }\end{array}$} & \multirow[b]{2}{*}{$\mathrm{T}$} & \multirow[b]{2}{*}{ Sig. } & \multicolumn{2}{|c|}{$\begin{array}{l}\text { Collinearity } \\
\text { Statistics }\end{array}$} \\
\hline & B & $\begin{array}{l}\text { Std. } \\
\text { Error }\end{array}$ & & & & Tolerance & VIF \\
\hline (Constant) & 10,127 & 2,315 & & 4,375 &, 000 & & \\
\hline $\begin{array}{l}\mathrm{X} 1=\text { Beta } \\
\operatorname{saham}(\beta)\end{array}$ & $-1,699$ & 1,845 &,- 144 &,- 921 & ,364 & ,999 & 1,001 \\
\hline $\begin{array}{l}\mathrm{X} 2=\text { debt } \\
\text { to equity } \\
\text { ratio (DER) }\end{array}$ &,- 037 & ,013 &,- 446 & 2,862 & ,007 & ,999 & 1,001 \\
\hline
\end{tabular}

a. Dependent Variable: $\mathrm{Y}=\mathrm{ROA}$ 
karena kolom Colinearity Statistics menunjukan hasil Tollerance diatas 0,1 dan Nilai Variation Inflasi Factor (VIF) tidak lebih dari 10 . Hasil Tollerance yang dihasilkan adalah 0,999 diatas 0,1 dan hasil VIF seluruhnya tidak lebih dari 10 yaitu 1,0001 sehingga bebas dari masalah multikolineritas

\section{Uji autokorelasi}

Uji ini bertujuan untuk menguji apakah ada hubungan otomatis antara variabel dependent dengan variabel independent. Hasilnya bebas dari masalah autokorelasi. Diuji dengan model Durbin Watson, gunakan Table Durbin Watson yaitu pada kolom $\mathrm{K}=2$ (jumlah variabel bebas) dan baris yang ke 35 (jumlah data).

Rentang jika auto korelasi tidak ada adalah sebagai berikut :

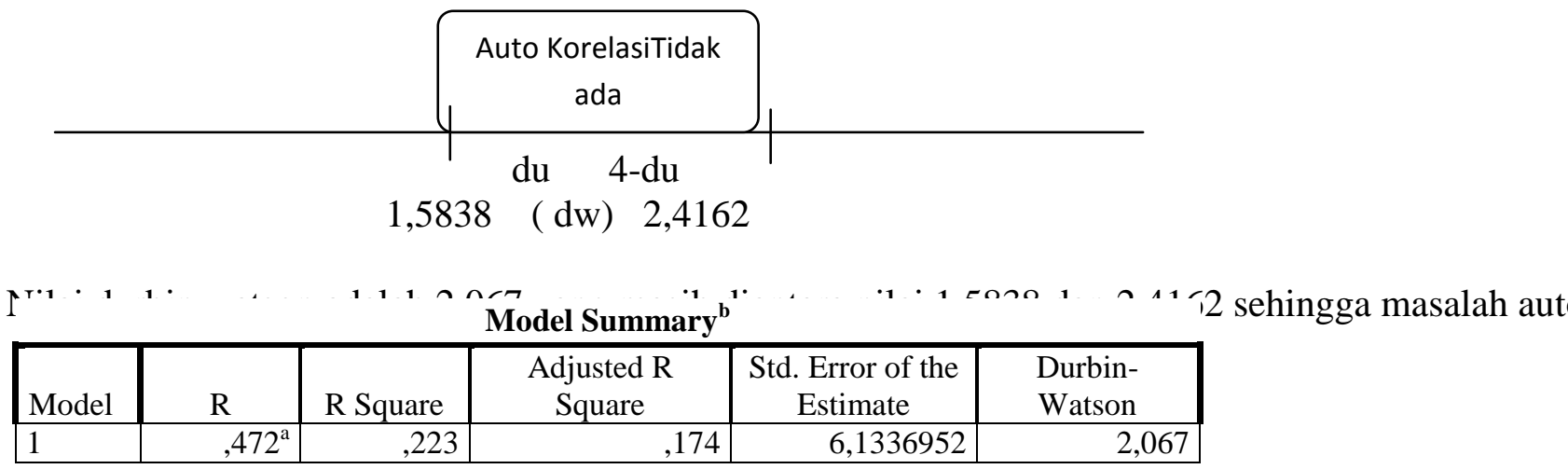

a. Predictors: (Constant), X2 = debt to equity ratio, $\mathrm{X} 1=$ Beta saham

b. Dependent Variable: $\mathrm{Y}=\mathrm{ROA}$

\section{Uji Heteroskedastisitas}

Uji ini bertujuan untuk memastikan bahwa data bersifat heterogen, secara umum tidak memiliki sifat pergerakan data yang sama, tidak menumpuk atau tidak membentuk pola garis tertentu.

Memperhatikan hasil gambar di bawah ini, data masih menyebar secara acak, dan dapat disimpulkan bahwa data bebas dari masalah heteroskedastisitas.

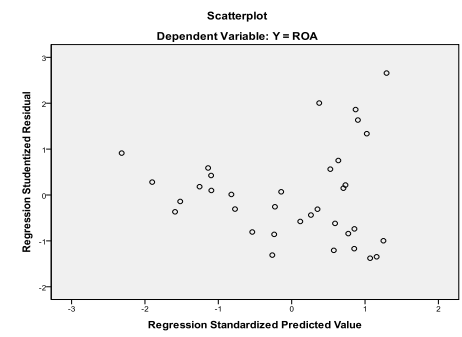


Dari gambar diatas terlihat data tersebar secara acak sehingga dapat disebut data adalah heterogen

\section{Uji Normalitas}

Uji normalitas dapat dilihat dari pergerakan data yang masih berada di sekitar garis diagonal. Artinya persamaan regresi yang dihasilkan akan bersifat BLUE (Best Linear Unbiased Estimation)

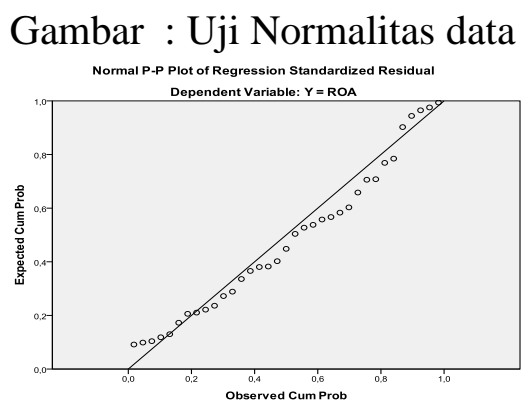

Dari gambar diatas bahwa pergerakan data masih berada di sekitar garis diagonal yang berarti akan menghasilkan persamaan regresi yang baik karena populasi data berdistribusi normal

\section{Uji Parsial (Uji t)}

Hasil uji regresi parsial, signifikan atau tidak dapat dilihat dengan beberapa cara. Salah satunya yaitu variabel $\mathrm{X}$ berpengaruh signifikan terhadap variabel $\mathrm{Y}$ apabila hasil sig < 0,05 atau dibawah $5 \%$.

\section{Coefficients $^{\mathrm{a}}$}

\begin{tabular}{|c|c|c|c|c|c|c|c|}
\hline \multirow[b]{2}{*}{ Model } & \multicolumn{2}{|c|}{$\begin{array}{l}\text { Unstandardized } \\
\text { Coefficients }\end{array}$} & \multirow{2}{*}{$\begin{array}{c}\begin{array}{c}\text { Standardized } \\
\text { Coefficients }\end{array} \\
\text { Beta }\end{array}$} & \multirow[b]{2}{*}{$\mathrm{T}$} & \multirow[b]{2}{*}{ Sig. } & \multicolumn{2}{|c|}{ Collinearity Statistics } \\
\hline & $\mathrm{B}$ & Std. Error & & & & Tolerance & VIF \\
\hline 1 (Constant) & 10,127 & 2,315 & & 4,375 &, 000 & & \\
\hline $\begin{array}{l}\mathrm{X} 1=\text { Beta } \\
\text { saham }\end{array}$ & $-1,699$ & 1,845 &,- 144 &,- 921 & ,364 & ,999 & 1,001 \\
\hline $\begin{array}{l}\mathrm{X} 2=\text { debt to } \\
\text { equity ratio }\end{array}$ &,- 037 &, 013 &,- 446 & $-2,862$ & ,007 & ,999 & 1,001 \\
\hline
\end{tabular}

a. Dependent Variable: $\mathrm{Y}=\mathrm{ROA}$

Hasil sig variabel X1 adalah 0,364 atau 36,4\%. Hasil sig untuk variabel X2 adalah 0,007 atau 0,7\% . Jadi hanya variabel X2 yang memiliki sig < 0,05. Dengan demikian berdasarkan cara tersebut, hanya variabel X2 yang berpengaruh signifikan terhadap Y yaitu variabel debt to equity ratio. 
Pengaruh yang dihasilkan untuk variabel $\mathrm{X} 1$ dan $\mathrm{X} 2$ adalah negatif, artinya bahwa pengaruh yang diberikan oleh $\mathrm{X} 1$ dan $\mathrm{X} 2$ terhadap $\mathrm{Y}$ adalah negatif artinya pengaruh variabel beta saham dan variabel debt to equity ratio tidak searah/ berlawanan Persamaan regresi yang terbentuk adalah $\mathrm{Y}=10,127-0,144 \mathrm{X} 1-0,446 \mathrm{X} 2+\mathrm{e}$. Artinya jika X1 dan X2 nol maka variabel Y akan konstan sebesar 10,127. Jika terjadi kenaikan X1 sebesar 1, maka akan terjadi penurunan Y sebesar 0,144 demikian juga sebaliknya jika X1 turun 1. Apabila terjadi kenaikan X2 sebesar 1 maka akan terjadi penurunan Y sebesar 0,446 dan demikian juga sebaliknya.

\section{Uji simultan (Uji F)}

Hasil uji simultan dapat dilihat dengan beberapa cara juga. Salah satu caranya yaitusecara bersama-sama variabel X1 dan X2 akan berpengaruh signifikan terhadap $\mathrm{Y}$ apabila Sig <0,05. Hasilnya pada table ANOVA dibawah ini menunjukan hasil sig 0,018 yang berarti bahwa secara bersama-sama variabel X1 dan X2 berpengaruh signifikan terhadap Y

\begin{tabular}{|ll|r|r|r|r|r|}
\hline \multicolumn{2}{|c|}{ ANOVA $^{\text {b }}$} \\
Model & $\begin{array}{c}\text { Sum of } \\
\text { Squares }\end{array}$ & Df & Mean Square & F & \multicolumn{1}{c|}{ Sig. } \\
\hline 1 & Regression & 344,769 & 2 & 172,384 & 4,5 &, $018^{\mathrm{a}}$ \\
& & & & & 82 & \\
& Residual & 1203,911 & 32 & 37,622 & & \\
& Total & 1548,680 & 34 & & & \\
\hline
\end{tabular}

a. Predictors: (Constant), X2 = debt to equity ratio, $\mathrm{X} 1=$ Beta saham

b. Dependent Variable: $\mathrm{Y}=\mathrm{ROA}$

Persamaan regresi yang terbentuk adalah $\mathrm{Y}=10,127-0,144 \mathrm{X} 1-0,446 \mathrm{X} 2+\mathrm{e}$. dapat digunakan secara bersama-sama variabel X1 dan X2 karena secara bersama-sama pengaruhnya terhadap ROA (Return on asset) signifikan model regresi ini dibawah 5 $\%$

\section{Koefisien Determinasi}

\begin{tabular}{|l|c|r|r|r|r|}
\hline \multicolumn{7}{|c|}{ Model Summary $^{\mathbf{b}}$} \\
\hline Model & $\mathrm{R}$ & R Square & $\begin{array}{c}\text { Adjusted R } \\
\text { Square }\end{array}$ & $\begin{array}{l}\text { Std. Error of } \\
\text { the Estimate }\end{array}$ & $\begin{array}{r}\text { Durbin- } \\
\text { Watson }\end{array}$ \\
\hline 1 &, $472^{2}$ &, 223 &, 174 & 6,1336952 & 2,067 \\
\hline
\end{tabular}


Koefisien determinasi adalah kemampuan seluruh variabel bebas dalam menjelaskan variabel terikat. Koefisien determinasi Adjusted R Square sebesar 0,174 atau sebesar 17,4 \% yang berarti bahwa kemampuan variabel X1 dan X2 dalam menjelaskan variabel $\mathrm{Y}$ adalah sebesar 17,4 \% sedangkan sisa sebesar 82,6\% dijelaskan oleh variabel lain diluar dari varibel penelitian ini atau disebut error dalam persamaan regresi ini.

R sebesar 0,472 memiliki arti bahwa korelasi bergandanya adalah sedang . Tingkat error yang dihasilkan dalam persamaan regresi dari hasil penelitian ini adalah 0,826 atau $82,6 \%$

\section{KESIMPULAN DAN SARAN}

Hasil penelitian terlihat bahwa keadaan yang terjadi terhadap saham-saham perusahaan di bursa efek Indonesia adalah :

1. Pengaruh beta saham $(\beta)$ terhadap Return on Asset (ROA) adalah negatif tidak signifikan sebesar 0,364 .

2. Pengaruh beta saham debt to equity ratio terhadap ROA di Bursa Efek Indonesia adalah negatif signifikan sebesar 0,007

3. Hasil penelitian menunjukan bahwa secara simultan atau bersama-sama Beta saham $(\beta)$ dan debt to equity ratio (DER) pengaruhnya signifikan terhadap ROA sebesar 0,018 dan persamaan regresi untuk model tersebut adalah ROA = $10,127-0,144$ beta saham $-0,446$ debt to equity ratio $+\mathrm{e}$

4. Dari hasil koefisien determinasi Adjusted $\mathrm{R}$ square sebesar 0,174 atau sebesar $17,4 \%$ pengaruh variabel beta saham dan debt to equity ratio terhadap variabel ROA adalah sebesar 17,4\% sedangkan sisanya sebesar 82,6\% dipengaruhi variabel lain di luar variabel penelitian.

5. Korelasi bergandanya adalah sebesar 0,472termasuk sedang dan tingkat error yang dihasilkan persamaan regresi dari penelitian sebesar $82,6 \%$

Dari kesimpulan diatas saran yang diberikan adalah sebagai berikut :

1. Persamaan regresi hasil penelitian ini secara bersama-sama variabel $x$ mempengaruhi variabel $\mathrm{Y}$ adalah signifikan sehingga bisa digunakan untuk memprediksi ROA.

2. Korelasi bergandanya adalah 0,472 yang berarti sedang sehingga ada hubungan bersama-sama antara beta saham dan Debt to equity ratio terhadap ROA. 
3. Informasi prediksi ROA ini dapat melengkapi informasi investor dalam membeli saham berdasarkan ukuran beta saham yaitu jika beta saham $>1$ maka resiko sistematisnya lebih besar dari resiko pasar sehingga diharapkan return yang akan diterima juga besar dan jika beta saham $<1$ maka resiko sistematisnya kecil dan return yang diharapkan investor adalah kecil.

4. Dari persamaan Regresi $\mathrm{ROA}=10,127-0,144$ beta saham -0,446 DER Maka jika beta saham naik 1 dan Debt to equity ratio naik 1 maka ROA akan turun 0,144 ditambah 0,446 . Jika beta naik tinggi atau DER juga naik tinggi maka ROA akan negatif. Jika kebijakan hutang tidak terkontrol maka kemungkinan net income perusahaan akan negatif yaitu net income dari ROA akibat rasio DER naik 2 rasio ROA turun 0,892 jika dianggap total asset tetap maka net income akan turun dari persamaan diatas mungkin disebabkan membayar biaya bunga yang semakin tinggi.

Beta yang naik berarti sistematika risk tinggi yang akan dapat menurunkan net income sedangkan beta yang tinggi maka ekses return saham juga tinggi dibandingkan ekses return Indek Harga Saham Gabungan (IHSG)

Bisa dilihat dari Rumus CAPM yaitu $E(r)=R f+\beta(R m-R f)$

5. Jika perusahaan terlalu beresiko maka Net Income juga akan turun.

\section{DAFTAR PUSTAKA}

Abdul Halim, "Analisis Investasi” edisi pertama Salemba Empat (PT Salemba Emban Patria), 2003

David K Eitman, Arthur I. Stonehill, Michael H. Moffett, "Multinational Business Finance" 9th edition, Addison Wesley Publishing Company Inc, 2001

Firdaus A. Dunia, "Ikhtisar Lengkap Pengantar Akuntansi", edisi kedua, Lembaga Penerbit Fakultas Ekonomi Universitas Indonesia, 2005

Iskandar Z. Alwi, “Pasar Modal Teori dan Aplikasi ” Yayasan Pancur Siwah Jl. Gelong Baru Utara, Jakarta 2003

Jerry J. Weygandt, Donald E. Kieso, Walter G. Kell, “Accounting Principles” fourth edition, John Wiley \& Sons, Inc, United States of Amerika, 1996

Keown, Arthur J, John D.Martin, J. Wiliam Petty, David F.Scott Jr, "Financial Management, Principles and Application" 10th edition, Prentice Hall International Inc 2005. 
Ross, Stephen A, Randolph W, Westerfield, Bradford D. Jordan "Fundamentals of Corporate Finance" 9th edition, McGraw Hill 2010.

Zvi Bodie, Alex Kane, Alan J. Marcus, "Investments", McGraw Hill Companies.Inc, Copyright 2002.

Power Point Internet, "Pelatihan SPSS dan Aplikasinya Regresi Berganda - Data Keuangan (Sekunder)", SiharTambun, Fakultas Ekonomi dan Bisnis Universitas 17 Agustus 1945, Jakarta, 2016 dari (http://www.google.com)

http:// www.yahoo.com/finance

http:// www.reuters.com/financial

http:// www.google.com/ google cendekia 